Article

\title{
Enhanced Ni-Al-Based Catalysts and Influence of Aromatic Hydrocarbon for Autothermal Reforming of Diesel Surrogate Fuel
}

\author{
Dong Geon Ju ${ }^{1,2,+}$, Seong Bin Jo ${ }^{3,+}$, Dong Su Ha ${ }^{4}$, Tae Young Kim ${ }^{1}$, Suk Yong Jung ${ }^{5}$, \\ Ho Jin Chae ${ }^{3} \mathbb{D}$, Soo Chool Lee ${ }^{3, *}$ and Jae Chang Kim ${ }^{1, *}$ \\ 1 Department of Chemical Engineering, Kyungpook National University, Daegu 41566, Korea \\ 2 Korea Evaluation Institute of Industrial Technology (KEIT), Daegu 41069, Korea \\ 3 Research Institute of Advanced Energy Technology, Kyungpook National University, Daegu 41566, Korea \\ 4 Korea Institute of Energy Research, Daejeon 34129, Korea \\ 5 Wonik Materials Co., Cheongju 28125, Korea \\ * Correspondence: soochool@knu.ac.kr (S.C.L.); kjchang@knu.ac.kr (J.C.K.); \\ Tel.: +82-53-950-5622 (J.C.K. \& S.C.L.) \\ + Dong Geon Ju and Seong Bin Jo contributed equally to this work.
}

Received: 23 May 2019; Accepted: 26 June 2019; Published: 28 June 2019

\begin{abstract}
Aromatic hydrocarbons along with sulfur compounds in diesel fuel pose a significant threat to catalytic performances, due mainly to carbon deposition on the catalytic surface. In order to investigate the influence of an aromatic hydrocarbon on the autothermal reforming of diesel fuel, 1-methylnaphthalene $\left(\mathrm{C}_{11} \mathrm{H}_{10}\right)$ was selected as an aromatic hydrocarbon. Two types of diesel surrogate fuel, i.e., $\mathrm{DH}$ (dodecane $\left(\mathrm{C}_{12} \mathrm{H}_{26}\right)$ and hexadecane $\left(\mathrm{C}_{16} \mathrm{H}_{34}\right)$ mixture) as well as DHM (DH fuel and $\mathrm{C}_{11} \mathrm{H}_{10}$ mixture) fuel, were prepared. A Rh-Al-based catalyst (R5A-I) was prepared using a conventional impregnation method. Various Ni-Al-based catalysts with Fe and Rh promoters were prepared via a polymer modified incipient method to improve the carbon coking resistance. These catalysts were tested under conditions of $\mathrm{S} / \mathrm{C}=1.17, \mathrm{O}_{2} / \mathrm{C}=0.24,750{ }^{\circ} \mathrm{C}$, and $\mathrm{GHSV}=12,000 \mathrm{~h}^{-1}$ at DH or DHM fuel. R5A-I exhibited excellent catalytic performance in both DH and DHM fuels. However, carbon coking and sulfur poisoning resistance were observed in our previous study for the Ni-Al-based catalyst with the Fe promoter, which became deactivated with increasing reaction time at the DHM fuel. In the case of the Rh promoter addition to the Ni-Al-based catalysts, the catalytic performances decreased relatively slowly with increasing (from $1 \mathrm{wt}$ \% (R1N50A) to $2 \mathrm{wt}$ \% (R2N50A)) content of $\mathrm{Rh}_{2} \mathrm{O}_{3}$ at DHM fuel. The catalysts were analyzed via scanning electron microscopy combined with energy dispersive X-ray, X-ray diffraction, and X-ray photoelectron spectroscopy. Gas chromatography-mass spectrometry detected various types of hydrocarbons, e.g., ethylene $\left(\mathrm{C}_{2} \mathrm{H}_{4}\right)$, with catalyst deactivation. The results revealed that, among the produced hydrocarbons, $\mathrm{C}_{2} \mathrm{H}_{4}$ played a major role in accelerating carbon deposition that blocks the reforming reaction. Therefore, Rh metal deserves consideration as a carbon coking inhibitor that prevents the negative effects of the $\mathrm{C}_{2} \mathrm{H}_{4}$ for autothermal reforming of diesel fuel in the presence of aromatic hydrocarbons.
\end{abstract}

Keywords: autothermal reforming; dodecane; hexadecane; 1-methylnaphthalene; nickel; rhodium; diesel; aromatic hydrocarbon

\section{Introduction}

Compared with other energy sources, hydrogen energy represents a cleaner and more sustainable energy, and has become one of the clean fuel options for reducing motor vehicle emissions. Hydrogen can be produced from a mixture of clean coal, fossil fuels, and nuclear power [1]. A hydrogen energy 
system is a complex system that includes production, utilization, and storage parts, and hydrogen utilization is difficult, due to the lack of hydrogen-supply infrastructure. In particular, hydrogen storage in safe, inexpensive, and lightweight storage vessels has been accomplished [2,3]. Furthermore, auxiliary power unit (APU) systems have been considered as on-board fuel processors. Hydrocarbon fuels, such as gasoline and diesel fuel, are used to operate the engines of most vehicles. Hydrogen, which is attainable through a catalytic reforming process performed on hydrocarbon fuels, can be used to generate electrical energy for fuel cells [4-6]. Notably, solid oxide fuel cell (SOFC)-based APU systems that use diesel fuel are unique alternatives because this fuel takes advantage of the high hydrogen density and existing fuel infrastructure [7-9]. Various reforming methods, including steam reforming (SR), partial oxidation (POX), and autothermal reforming (ATR), may be used to generate hydrogen-rich gases for APU systems. A water gas shift reaction (WGSR) may occur in the presence of $\mathrm{CO}$ and excessive steam. The corresponding reforming reactions are given as follows:

(1) SR: $\mathrm{C}_{\mathrm{n}} \mathrm{H}_{\mathrm{m}}+\mathrm{nH}_{2} \mathrm{O} \rightarrow(\mathrm{m} / 2+\mathrm{n}) \mathrm{H}_{2}+\mathrm{nCO}$

(2) POX: $\mathrm{C}_{\mathrm{n}} \mathrm{H}_{\mathrm{m}}+(\mathrm{n} / 2) \mathrm{O}_{2} \rightarrow(\mathrm{m} / 2) \mathrm{H}_{2}+\mathrm{nCO}$

(3) ATR: $\mathrm{C}_{\mathrm{n}} \mathrm{H}_{\mathrm{m}}+(\mathrm{n} / 2) \mathrm{H}_{2} \mathrm{O}+(\mathrm{n} / 4) \mathrm{O}_{2} \rightarrow(\mathrm{m}+\mathrm{n}) / 2 \mathrm{H}_{2}+\mathrm{nCO}$

(4) WGSR: $\mathrm{CO}+\mathrm{H}_{2} \mathrm{O} \leftrightarrow \mathrm{H}_{2}+\mathrm{CO}_{2}$

ATR combines endothermic SR with exothermic POX. In other words, hydrocarbon fuels react with air and steam, which generates hydrogen-rich gas. Compared with the conventional reforming methods, ATR as a potential reforming method exhibits higher energy efficiency and thermal stability [10-17]. The production technologies of green diesel have studied for combustion engines with remarkable properties and significantly lower emissions [18]. The complexity of a typical commercial diesel fuel composition prevents exact modeling of such compositions. Due to sulfur poisoning and carbon deposition, low aromatic and sulfur compounds in diesel fuels lead to significant deterioration of the catalytic performance [19-21]. Many catalysts have been prepared and tested for reforming hydrocarbon fuel. Methane, biogas, and glycerol were employed as feedstock for the production of syngas $\left(\mathrm{CO}+\mathrm{H}_{2}\right)$ as well as gasoline and diesel fuel [22-25]. Additionally, the role of the oxide support in the catalytic performance of ATR performed on a gasoline surrogate fuel was determined by testing $\mathrm{Rh}$ catalysts with various supports $\left(\mathrm{Gd}-\mathrm{CeO}_{2}, \mathrm{Y}-\mathrm{ZrO}_{2}, \gamma-\mathrm{Al}_{2} \mathrm{O}_{3}, \mathrm{La}-\mathrm{Al}_{2} \mathrm{O}_{3}\right.$, and $\mathrm{CaAl}_{12} \mathrm{O}_{19}$ ) [26]. Ni-catalysts supported on modified alumina (-La, $-\mathrm{Ba}$, and -Ce) were studied with the aim to improve the catalytic performance associated with steam reforming of diesel fuel [27]. $\mathrm{Pt} / \mathrm{CeO}_{2}-\mathrm{Al}_{2} \mathrm{O}_{3}$ was investigated for numerical simulation of diesel reforming [28]. Rh-Ni-based catalysts showed high activity and stability for methane reforming by the addition of $\mathrm{Rh}[29,30]$. Jet fuel in the absence and presence of sulfur was conducted by $\mathrm{Rh}$ and $\mathrm{Rh}-\mathrm{Ni}$ loaded on $\mathrm{CeO}_{2}$-modified $\mathrm{Al}_{2} \mathrm{O}_{3}$ support for steam reforming [31]. Furthermore, novel-metal-based ( $\mathrm{RhPt} / \mathrm{ZrO}_{2}, \mathrm{Al}_{2} \mathrm{O}_{3}, \mathrm{CeO}_{2}-\mathrm{ZrO}_{2}$, $\mathrm{SiO}_{2}$, and $\mathrm{TiO}_{2}, \mathrm{Rh}-\mathrm{Ni} / \mathrm{Al}_{2} \mathrm{O}_{3}$ ) catalysts were evaluated for reforming diesel fuel in the presence of sulfur compounds [32-36]. Rh-based catalysts were prepared via microemulsion and a zone-coating preparation method for diesel reforming $[37,38]$ and also sorption-hydrolytic deposition conducted for highly dispersed $\mathrm{Rh}$-, $\mathrm{Pt}$-, and $\mathrm{Ru} / \mathrm{Ce}_{0.75} \mathrm{Zr}_{0.25} \mathrm{O}_{2}-\delta$ catalysts [39]. $\mathrm{Rh} / \mathrm{Ce}_{0.75} \mathrm{Zr}_{0.25} \mathrm{O}_{2-\delta}-\eta-\mathrm{Al}_{2} \mathrm{O}_{3} / \mathrm{FeCrAl}$ were tested in pilot scale reactors with autothermal reforming of $\mathrm{n}$-hexadecane. The produced syngas can be supplied as a fuel for power generation units based on SOFC [40]. In our previous studies, a polymer modified incipient method (PM) was introduced as a timesaving and promising alternative preparation method to conventional preparation methods, such as impregnation or co-precipitation methods [41]. Moreover, sulfur-resistant Ni-Al-based catalysts with added Fe promoters were prepared by means of the PM method for autothermal reforming of dodecane [42]. The role of these catalysts in diesel surrogate fuel containing aromatic hydrocarbons has, however, remained unexplored. Therefore, in this study, Ni-Al-based catalysts were tested in the presence of aromatic hydrocarbon such as 1-methylnaphthalene $\left(\mathrm{C}_{11} \mathrm{H}_{10}\right)$ and, ultimately, attempt to enhance catalytic performances. The ethylene $\left(\mathrm{C}_{2} \mathrm{H}_{4}\right)$ was considered a major contributor to catalyst deactivation that results in rapid coke formation during the reforming process $[43,44]$. The produced hydrocarbons $\left(\right.$ e.g., $\left.\mathrm{C}_{2} \mathrm{H}_{4}\right)$ were detected via 
GC-MS to identify the hydrocarbon that plays the major role in this deactivation in the presence of aromatic hydrocarbon. Furthermore, the catalysts were characterized by means of field emission scanning electron microscopy (FE-SEM) in conjunction with energy dispersive X-ray (EDX), X-ray diffraction (XRD), and X-ray photoelectron spectroscopy (XPS).

\section{Results and Discussion}

\subsection{Catalytic Performances in the Absence and Presence of Aromatic Hydrocarbon}

The experiments were performed at $\mathrm{S} / \mathrm{C}=1.17, \mathrm{O}_{2} / \mathrm{C}=0.24,750{ }^{\circ} \mathrm{C}$, and $\mathrm{GHSV}=12,000 \mathrm{~h}^{-1}$, for comparison with the catalytic performances realized in the presence of aromatic hydrocarbons such as 1-methylnaphthalene $\left(\mathrm{C}_{11} \mathrm{H}_{10}\right)$. Figure 1 shows the conversions obtained for the blank test, R5A-I, N10A, and F10N10A at DH (dodecane $\left(\mathrm{C}_{12} \mathrm{H}_{26}\right)$ and hexadecane $\left(\mathrm{C}_{16} \mathrm{H}_{34}\right)$ mixture) and DHM (DH fuel and $\mathrm{C}_{11} \mathrm{H}_{10}$ mixture) fuels. A conversion of $\sim 33 \%$ was obtained for the blank test, with/without $\mathrm{C}_{11} \mathrm{H}_{10}$ in the diesel surrogate fuel. As shown in Figure 1a, conversions of $\sim 80 \%$ were obtained for 5 -hour periods of each catalyst at the DH fuel. However, the catalytic performances varied with the addition of $\mathrm{C}_{11} \mathrm{H}_{10}$ to the diesel surrogate fuel (see Figure $1 \mathrm{~b}$ ). The catalytic performances of N10A and F10N10A deteriorated significantly within 1 hour and, thereafter, the conversions remained the same as that of the blank test, which suggests that the catalysts were completely deactivated. The addition of $\mathrm{Fe}$ as a promoter to Ni-Al-based catalysts enhances carbon coking and the sulfur poisoning resistance, as reported in our previous study [42]. However, this addition had a negative effect in the presence of the aromatic hydrocarbon. Although the conversion of R5A-I at DHM fuel was 10\% lower than that at the DH fuel, the catalytic performance of R5A-I was maintained for 5 hours. This indicated that R5A-I including Rh metal acted as an excellent catalyst at the DHM fuel.
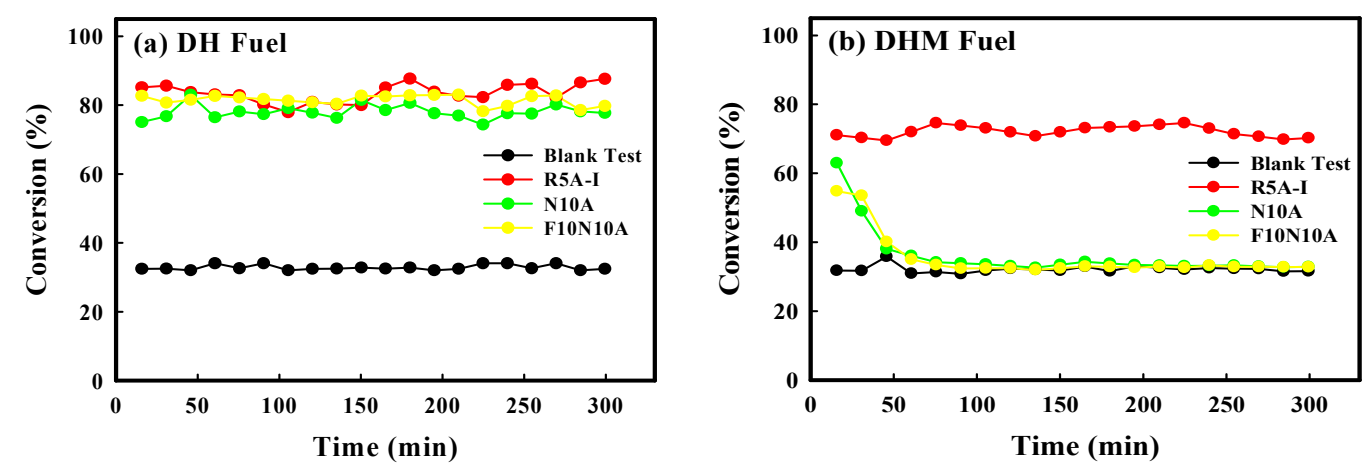

Figure 1. Conversions corresponding to the blank test, R5A-I, N10A, and F10N10A at: (a) DH and (b) DHM fuel.

The selectivity of product gas (\%) of the blank test, R5A-I, N10A, and F10N10A at DH and DHM fuel is shown in Figure 2. For the blank test and R5A-I, the percentage of $\mathrm{H}_{2}, \mathrm{CO}, \mathrm{CH}_{4}$, and $\mathrm{CO}_{2}$ produced in the absence and presence of $\mathrm{C}_{11} \mathrm{H}_{10}$ was almost the same. Additionally, at the DH fuel, selective percentages of $\mathrm{H}_{2}, \mathrm{CO}, \mathrm{CH}_{4}$, and $\mathrm{CO}_{2}$ produced by R5A-I was similar to those generated by N10A and F10N10A. Approximately 59\%, 23\%, $1 \%$, and $17 \%$ of $\mathrm{H}_{2}, \mathrm{CO}, \mathrm{CH}_{4}$, and $\mathrm{CO}_{2}$ selectivity, respectively, were initially generated by deactivated catalysts such as N10A and F10N10A. The subsequent selectivity were nearly the same as those obtained for the blank test. In other words, selectivity of $\mathrm{H}_{2}$ and $\mathrm{CO}_{2}$ produced by N10A and F10N10A decreased with increasing time, while that of $\mathrm{CO}$ and $\mathrm{CH}_{4}$ increased until these catalysts were completely deactivated. Therefore, compared with the presence of $\mathrm{C}_{11} \mathrm{H}_{10}$, reaction conditions, such as $\mathrm{S} / \mathrm{C}, \mathrm{O}_{2} / \mathrm{C}$, and temperature, played a greater role in selectivity of product gas (\%), which is consistent with the findings of our previous study [45]. 

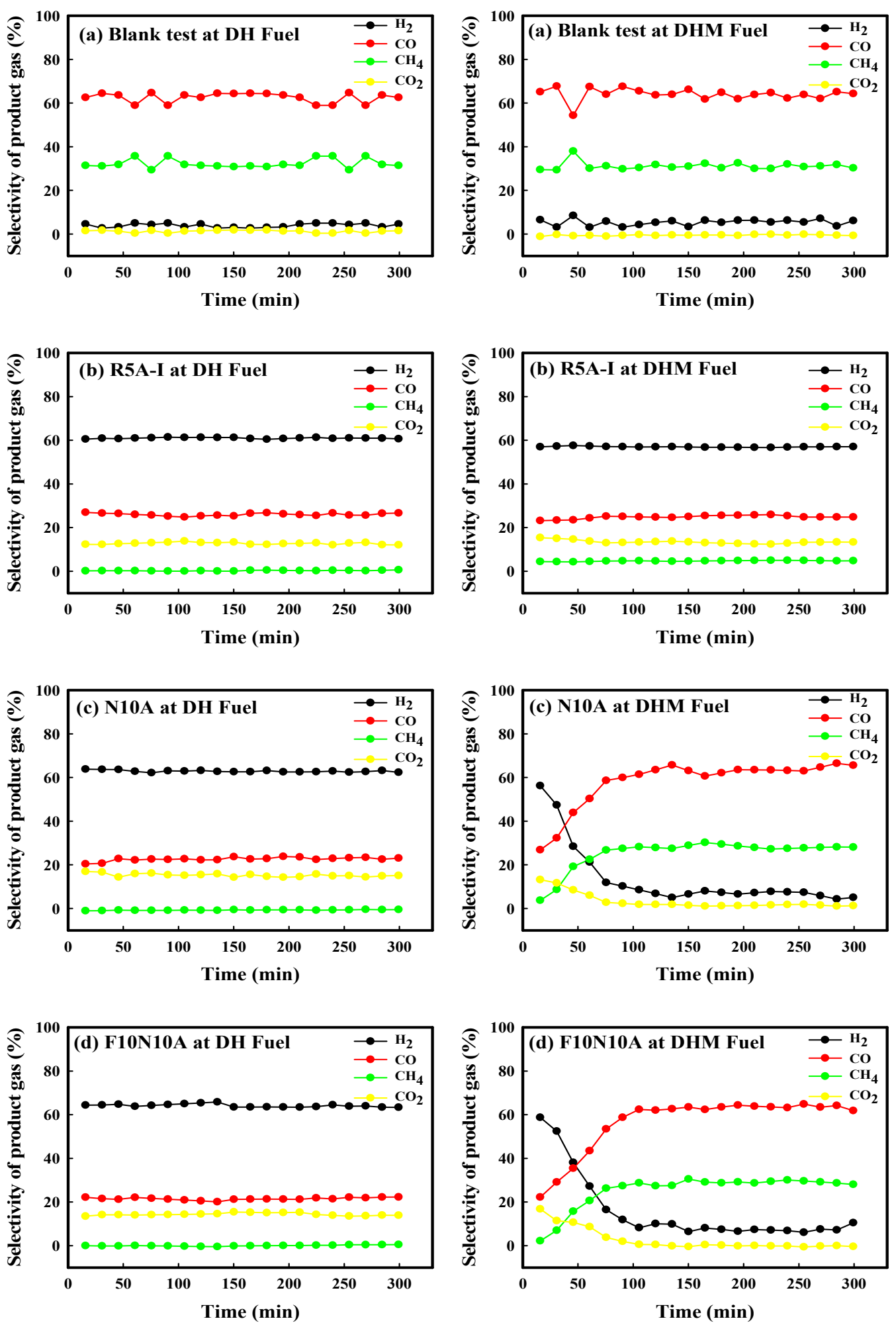

Figure 2. The selectivity of product gas (\%) of the (a) blank test, (b) R5A-I, (c) N10A, and (d) F10N10A at DH and DHM fuel.

The hydrocarbons produced after reforming were separately analyzed via GC-MS (see Table 1 for the blank test, R5A-I, N10A, and F10N10A data corresponding to 30-minute and 60-minute reactions at the DHM fuel). Small amounts of benzene $\left(\mathrm{C}_{6} \mathrm{H}_{6}\right)$ were produced in the case of R5A-I, but various types of hydrocarbons, which resulted in catalyst deactivation, were detected in N10A and F10N10A. High fractions of ethylene $\left(\mathrm{C}_{2} \mathrm{H}_{4}\right)$ formed in N10A and F10N10A after 60 minutes of reaction. The previously 
mentioned results suggested that the hydrocarbons produced after reforming had an adverse effect on the catalytic performance.

Table 1. Data obtained from the GC-MS of the blank test, R5A-I, N10A, and F10N10A after 30-minute and 60-minute reactions at the DHM fuel.

\begin{tabular}{ccccccccc}
\hline & \multicolumn{2}{c}{ Blank Test } & \multicolumn{2}{c}{ R5A-I } & \multicolumn{2}{c}{ N10A } & \multicolumn{2}{c}{ F10N10A } \\
\hline Reaction Time $(\mathbf{m i n})$ & $\mathbf{3 0}$ & $\mathbf{6 0}$ & $\mathbf{3 0}$ & $\mathbf{6 0}$ & $\mathbf{3 0}$ & $\mathbf{6 0}$ & $\mathbf{3 0}$ & $\mathbf{6 0}$ \\
\hline Carbon dioxide $\left(\mathrm{CO}_{2}\right)$ & 8.2 & 8.2 & 98.3 & 98.2 & 39.5 & 21.2 & 55.7 & 25.8 \\
Ethane $\left(\mathrm{C}_{2} \mathrm{H}_{6}\right)$ & 2.3 & 2.3 & - & - & 3.2 & 2.8 & 2.9 & 2.7 \\
Ethylene $\left(\mathrm{C}_{2} \mathrm{H}_{4}\right)$ & 32.2 & 32.2 & - & - & 28.6 & 30.9 & 20.7 & 29.9 \\
Propylene $\left(\mathrm{C}_{3} \mathrm{H}_{6}\right)$ & 16.4 & 16.4 & - & - & 13.1 & 15.9 & 7.8 & 14.7 \\
1,3-Butadiene $\left(\mathrm{C}_{4} \mathrm{H}_{6}\right)$ & 9.4 & 9.4 & - & - & 4.9 & 8.1 & 3.0 & 7.7 \\
1,3-Cyclopentadiene $\left(\mathrm{C}_{5} \mathrm{H}_{6}\right)$ & 4.5 & 4.5 & - & - & 0.9 & 2.9 & 0.4 & 2.6 \\
Benzene $\left(\mathrm{C}_{6} \mathrm{H}_{6}\right)$ & 16.2 & 16.2 & 0.2 & 0.3 & 9.7 & 11.1 & 7.9 & 11.7 \\
Toluene $\left(\mathrm{C}_{7} \mathrm{H}_{8}\right)$ & 4.2 & 4.2 & - & - & - & 2.4 & 1.1 & 2.1 \\
\hline
\end{tabular}

\subsection{Catalyst Analysis before and after Reaction in the Absence and Presence of Aromatic Hydrocarbon}

Catalyst deactivation by hydrocarbons production was verified via SEM-EDX, XRD, and XPS analysis. The morphology and amounts of carbon on the catalytic surface were determined by SEM-EDX analysis. High-magnification (10,000x) SEM images reveal the wire shape of carbon deposited on the surface of N10A and F10N10A after a 5-hour reaction at DH and DHM fuel (see Figure 3). Moreover, the amount of carbon coking at DH fuel was expected to be lower than that at the DHM fuel because the previously mentioned wire shape occurred more frequently at DHM fuel. The amounts of carbon on the catalytic surface of R5A-I, N10A, and F10N10A after 5-hour reactions at DH and DHM fuel are listed in Table 2. In the case of R5A-I, $21 \mathrm{wt} . \%$ of carbon occurred on the surface irrespective of the diesel surrogate fuel considered. At the DHM fuel, $47.21 \mathrm{wt} . \%$ and $45.08 \mathrm{wt} . \%$ of carbon were deposited on the catalytic surface of N10A and F10N10A, respectively, and these amounts were more than twice those occurring at $\mathrm{DH}$ fuel. In our previous study, Ni-Al-based catalyst and Fe-Ni-Al-based catalyst at $\mathrm{D}$ fuel $\left(\mathrm{C}_{12} \mathrm{H}_{26}\right)$ in the presence of DBT were $33.4 \mathrm{wt} . \%$ and $8.58 \mathrm{wt} . \%$, respectively [42]. In particular, the amount of carbon increased more in the case of Fe-Ni-Al-based catalyst at DHM fuel, compared to those at D fuel in the presence of DBT and DH fuel. Thus, it was concluded that the addition of Fe to Ni-Al-based catalyst had no effect to prevent carbon deposition on the catalytic surface. Moreover, SEM-EDX analysis revealed that hydrocarbon production promotes carbon deposition on the catalytic surface.

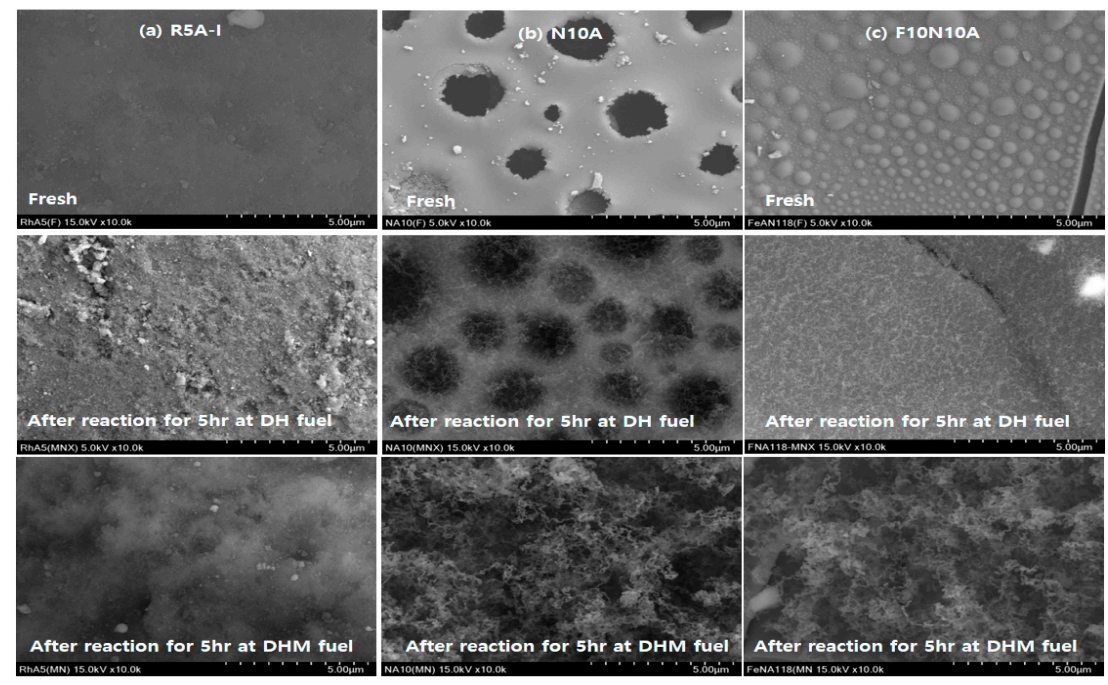

Figure 3. Scanning electron micrographs of (a) R5A-I, (b) N10A, and (c) F10N10A. 
Table 2. Amounts of carbon on the catalytic surface of R5A-I, N10A, and F10N10A after 5-hour reactions at $\mathrm{DH}$ and DHM fuel.

\begin{tabular}{ccccccc}
\hline & \multicolumn{2}{c}{ R5A-I } & \multicolumn{2}{c}{ N10A } & \multicolumn{2}{c}{ F10N10A } \\
\hline Fuel & DH & DHM & DH & DHM & DH & DHM \\
\hline Carbon (wt. $\%)$ & 21.59 & 20.89 & 19.96 & 47.21 & 20.78 & 45.08 \\
\hline
\end{tabular}

The crystal structure of R5A-I, N10A, and F10N10A were characterized via X-ray diffraction (XRD) analysis (see Figure 4). $\mathrm{Rh}_{2} \mathrm{O}_{3}, \mathrm{NiO}$, and $\mathrm{Fe}_{2} \mathrm{O}_{3}$ were undetected in the fresh state. The incorporation of $\mathrm{Ni}^{2+}$ ions into $-\mathrm{Al}_{2} \mathrm{O}_{3}\left(\mathrm{NiAl}_{2} \mathrm{O}_{4}\right)$ resulted in the lattice expansion of $-\mathrm{Al}_{2} \mathrm{O}_{3}$ and, hence, the diffraction peak of $\mathrm{NiAl}_{2} \mathrm{O}_{4}$ is shifted to a lower diffraction angle, i.e., $66.84^{\circ}$, compared with that of $-\mathrm{Al}_{2} \mathrm{O}_{3}$. The $\mathrm{NiAl}_{2} \mathrm{O}_{4}$ phase is inactive in the reforming reaction of hydrocarbons [45-47]. As shown in Figure $4 b, c$, the $\mathrm{Ni}$ and $\mathrm{FeNi}$ phase were observed after the $\mathrm{H}_{2}$ pre-reduction treatment and 5-hour reaction at $\mathrm{DH}$ fuel. However, these phases were absent from the XRD pattern associated with the 5-hour reaction at DHM fuel. The XRD pattern of each catalyst was almost identical to those of the fresh state, which suggests that detection of active metals (e.g., Ni or FeNi) was difficult, due to carbon deposition on the catalytic surface.
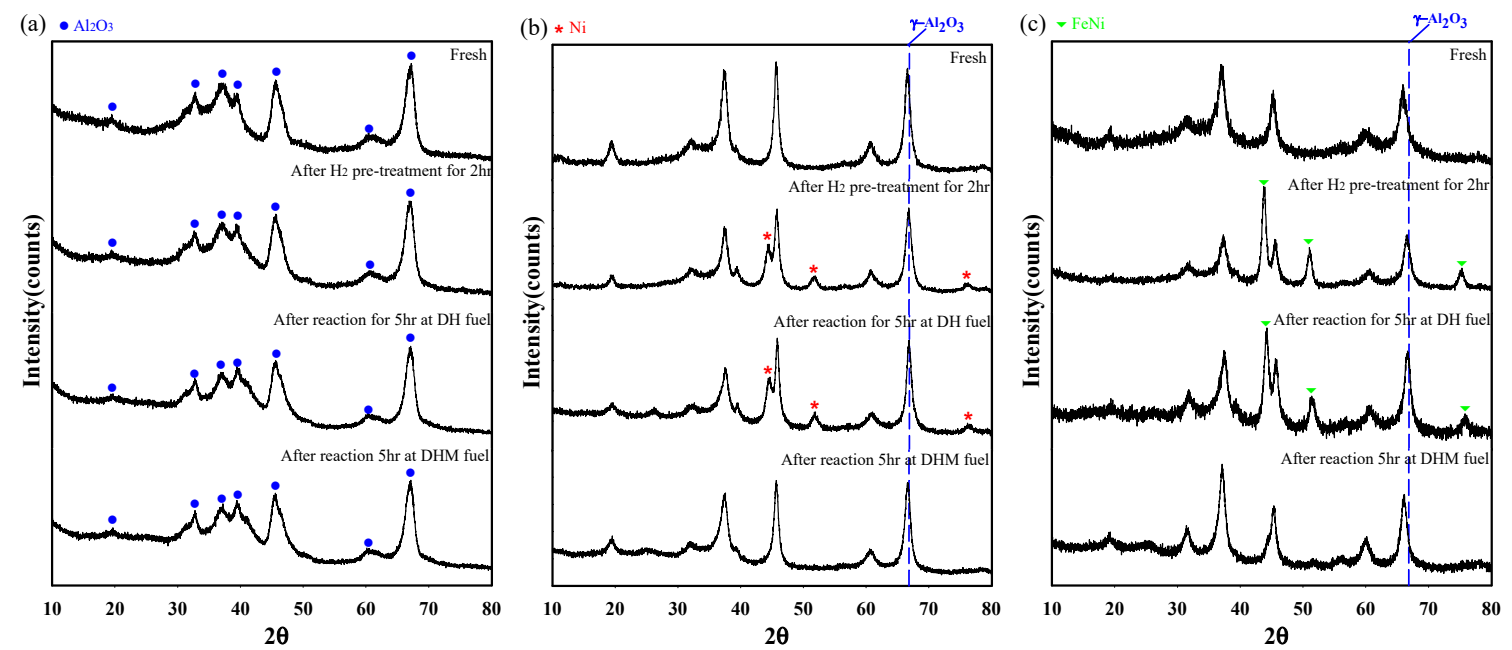

Figure 4. Results of XRD analysis performed on (a) R5A-I, (b) N10A, and (c) F10N10.

The phases comprising R5A-I, N10A, and F10N10A were investigated further via XPS analysis (see Figure 5). $\mathrm{Rh}_{2} \mathrm{O}_{3}, \mathrm{NiO}$, and $\mathrm{Fe}_{2} \mathrm{O}_{3}$ phases, which were undected by $\mathrm{XRD}$, were observed in the fresh state. The XPS peaks corresponding to $\mathrm{Rh} 3 \mathrm{~d} 5 / 2, \mathrm{Rh}_{2} \mathrm{O}_{3}$, and $\mathrm{Rh} 3 \mathrm{~d} 3 / 2$ occurred at binding energies of $307.6 \mathrm{eV}, 308.3 \mathrm{eV}$, and $312 \mathrm{eV}$ (see Figure 5a), respectively [48]. The peaks of Rh3d5/2 and $\mathrm{Rh} 3 \mathrm{~d} 3 / 2$ appeared after the $\mathrm{H}_{2}$ pre-reduction treatment and the 5-hour reaction at DH and DHM fuel. The $\mathrm{Rh} 3 \mathrm{~d} 5 / 2$ and $\mathrm{Rh} 3 \mathrm{~d} 3 / 2$ peaks appearing after this reaction were relatively sharper than those observed after the $\mathrm{H}_{2}$ pre-reduction treatment. The peaks of $\mathrm{Ni}, \mathrm{NiO}$, and $\mathrm{NiAl}_{2} \mathrm{O}_{4}$ are associated with binding energies of $853 \mathrm{eV}, 854 \mathrm{eV}$, and $856 \mathrm{eV}$, respectively [49], as shown in Figure 5b. However, the 5-hour reaction at DH and DHM fuels yielded indistinguishable Ni peaks. The peaks of FeNi and $\mathrm{Fe}_{2} \mathrm{O}_{3}$ occurred at binding energies of $710 \mathrm{eV}$ and $711 \mathrm{eV}$ (see Figure 5c), respectively [50]. The FeNi peak after the 5-hour reaction at DHM fuel was slightly smaller than that associated with the 5-hour reaction at $\mathrm{DH}$ fuel. The results indicated that the changes in the $\mathrm{Ni}$ and FeNi peaks result from carbon deposition on the catalytic surface during the reaction. Therefore, the produced hydrocarons such as $\mathrm{C}_{2} \mathrm{H}_{4}$ accelerated carbon deposition and inhibited the reforming reaction required for autothermal reforming of the diesel surrogate fuel. 

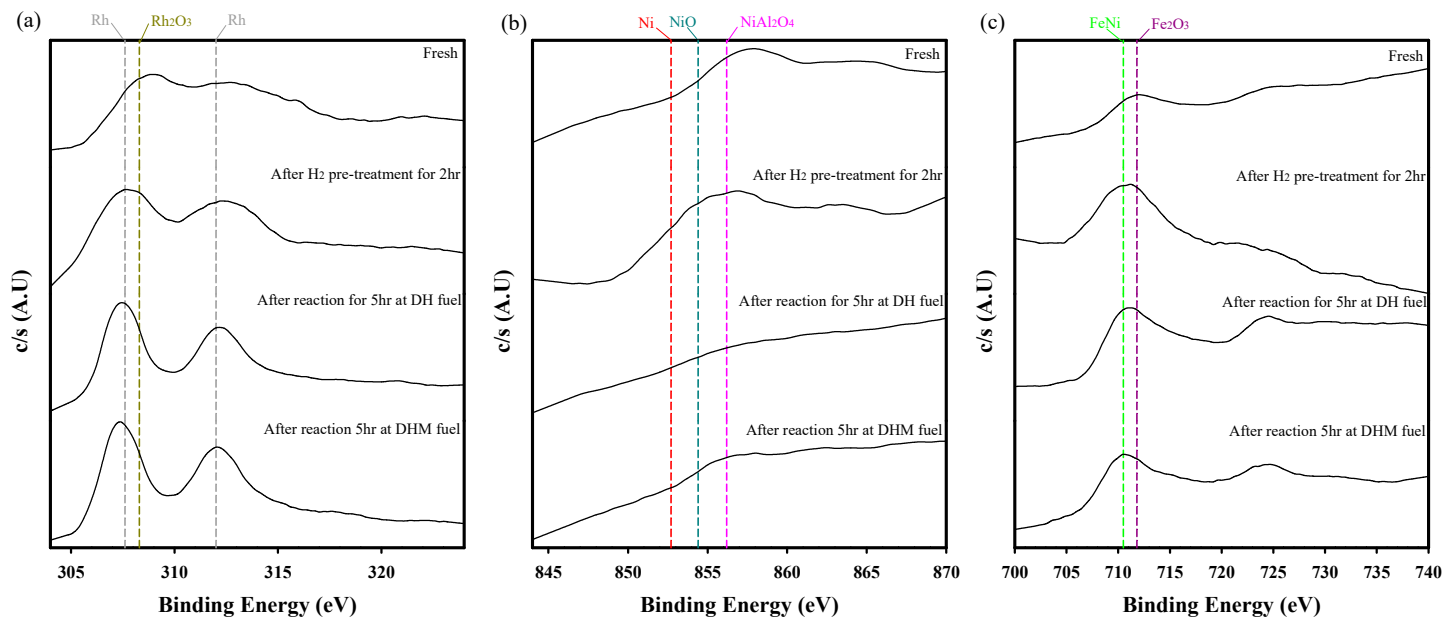

Figure 5. Results of XPS analysis performed on (a) R5A-I, (b) N10A, and (c) F10N10A.

2.3. Catalytic Performances of Ni-Al-Based Catalysts with Fe and Rh Promoters in the Presence of Aromatic Hydrocarbon

The resistance properties of aromatic hydrocarbon were investigated under the previously mentioned conditions. The catalytic performance of Ni-Al-based catalysts improved with increasing content of Ni metal (Supplementary Materials Figure S1). Research regarding the content of Ni metal for autothermal reforming of a diesel surrogate fuel will be presented in another study. Ni-Al-based catalysts with a $\mathrm{NiO}$ content of $50 \mathrm{wt} . \%$ were prepared and various amounts of Fe and Rh promoters were added to these catalysts to improve and prolong the catalytic performances of DHM fuel. The Ni-Al-based catalysts with different amounts $\left(\mathrm{Fe}_{2} \mathrm{O}_{3} 10 \mathrm{wt} . \%, 20 \mathrm{wt} . \%\right.$, and $\left.30 \mathrm{wt} . \%\right)$ of Fe promoter were tested using DHM fuel. The Fe promoter improves carbon coking and the sulfur poisoning resistance for autothermal reforming of dodecane [42] and was, hence, expected to prevent carbon deposition in the presence of aromatic hydrocarbons. Figure 6a reveals initial conversions of $72 \%$, $68 \%, 68 \%$, and $55 \%$ for the N50A, F10N50A, F20N50A, and F30N50A, respectively, using DHM fuel. Contrary to expectations, these catalysts were deactivated with increasing reaction time. A conversion of $\sim 33 \%$ was obtained for the blank test in Figure 1 . This conversion was a similar value with those for the N50A, F10N50A, F20N50A, and F30N50A at higher times. This conversion was obtained from DHM fuel thermally decomposed to $\mathrm{CO}, \mathrm{CO}_{2}$, and $\mathrm{CH}_{4}$ after catalyst deactivation. Furthermore, catalytic performances of DHM fuel deteriorated with the increasing amount of Fe promoter, i.e., this promoter yielded no improvement in the catalytic performance in the presence of aromatic hydrocarbons, such as $\mathrm{C}_{11} \mathrm{H}_{10}$. Small amounts $\left(\mathrm{Rh}_{2} \mathrm{O}_{3} 1 \mathrm{wt} . \%\right.$ and $\left.2 \mathrm{wt} . \%\right)$ of $\mathrm{Rh}$ promoter as alternatives to the Fe promoter were added to the Ni-Al-based catalysts to resolve the problem of catalyst deactivation. Figure $6 \mathrm{~b}$ reveals an initial conversion of $\sim 70 \%$ for the R5A-I, N50A, R1N50A, and R2N50A using DHM fuel. The conversion of R5A-I was maintained for 5 hours, but the catalytic performances of N50A, R1N50A, and R2N50A deteriorated with increasing reaction time. R1N50A and R2N50A were more slowly deactivated than N50A. The deactivation rate of R2N50A was moderately reduced by increasing the content of $\mathrm{Rh}$ promoter. The addition of $\mathrm{Rh}$ to Ni-Al-based catalysts improved the dispersion of $\mathrm{Ni}$ and retarded the sintering of $\mathrm{Ni}$ by the strong interaction between $\mathrm{Rh}$ and $\mathrm{Ni}$ [29,30,33]. Although metallic $\mathrm{Rh}$ is a costly metal, the $\mathrm{Rh}$ promoter deserves consideration as a promoter for Ni-Al-based catalysts. For improved catalytic performance, further studies are required to identify a suitable promoter that yields autothermal reforming of diesel fuel. 

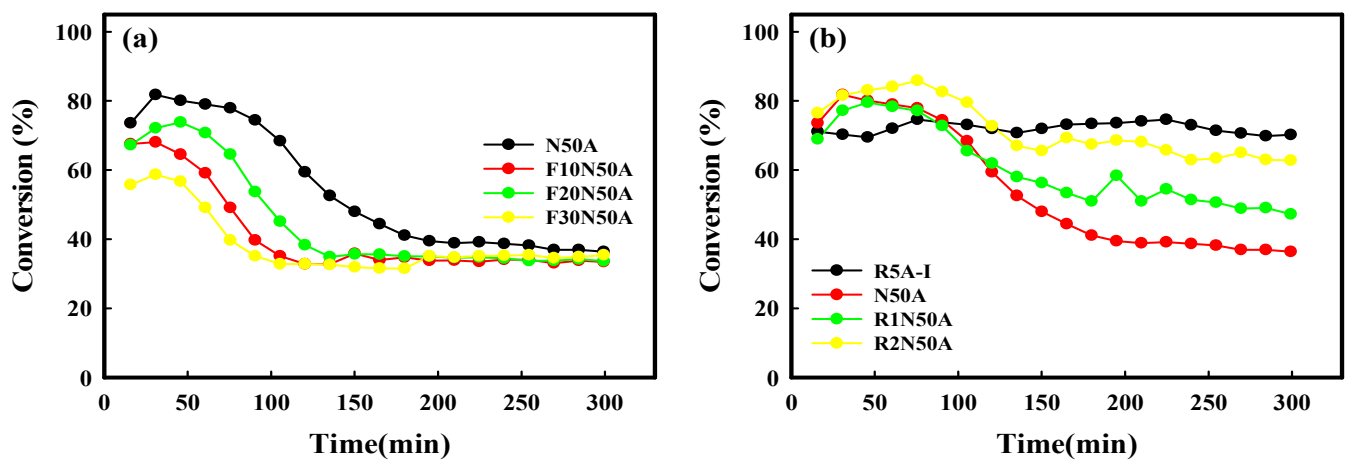

Figure 6. Conversions of the (a) N50A, F10N50A, F20N50A, and F30N50A and (b) R5A-I, N50A, R1N50A, and R2N50A of DHM fuel.

The basis for differences in the catalytic performance was investigated via GC-MS analysis of hydrocarbons such as $\mathrm{C}_{2} \mathrm{H}_{4}$. Table 3 shows the data corresponding to R5A-I, N50A, R1N50A, and R2N50A after the reaction for 30-minute and 300-minute using DHM fuel. The amount of hydrocarbons increased, in general, with increasing reaction time, whereas the amount of $\mathrm{CO}_{2}$ decreased. At fractions of $23.8 \%, 18.2 \%$, and $16.5 \%, \mathrm{C}_{2} \mathrm{H}_{4}$ accounted for the highest proportion of produced hydrocarbons in the case of N50A, R1N50A, and R2N50A, respectively, which reacted for 300 minutes. $\mathrm{C}_{6} \mathrm{H}_{6}$ accounted for the second-highest fraction of produced hydrocarbons. Neverthless, $\mathrm{C}_{6} \mathrm{H}_{6}$ had a negligible effect on catalyst deactivation, since R5A-I exhibited excellent catalytic performance, despite the high fraction of this hydrocarbon. As previously mentioned, we assumed that the produced hydrocarbons were associated with carbon deposition on the catalytic surface. The results indicated that, compared with the other hydrocarbons, the produced $\mathrm{C}_{2} \mathrm{H}_{4}$ plays a crucial role in catalyst deactivation, which is consistent with the results of previous studies $[43,44]$. More importantly, Rh metal seemed to play an important role in reducing $\mathrm{C}_{2} \mathrm{H}_{4}$ production, which accelerates carbon deposition.

Table 3. Data obtained from GC-MS of R5A-I, N50A, R1N50A, and R2N50A after 30-minute and 300-minute reactions of DHM fuel.

\begin{tabular}{ccccccccc}
\hline & \multicolumn{2}{c}{ R5A-I } & \multicolumn{2}{c}{ N50A } & \multicolumn{2}{c}{ R1N50A } & \multicolumn{2}{c}{ R2N50A } \\
\hline Reaction Time $(\mathbf{m i n})$ & $\mathbf{3 0}$ & $\mathbf{3 0 0}$ & $\mathbf{3 0}$ & $\mathbf{3 0 0}$ & $\mathbf{3 0}$ & $\mathbf{3 0 0}$ & $\mathbf{3 0}$ & $\mathbf{3 0 0}$ \\
\hline Carbon dioxide $\left(\mathrm{CO}_{2}\right)$ & 98.3 & 75.5 & 94.1 & 23.8 & 98.7 & 38.7 & 98.7 & 45.6 \\
Ethane $\left(\mathrm{C}_{2} \mathrm{H}_{6}\right)$ & - & 0.5 & - & 2.8 & - & 2.7 & - & 2.4 \\
Ethylene $\left(\mathrm{C}_{2} \mathrm{H}_{4}\right)$ & - & 0.3 & - & 23.8 & - & 18.2 & - & 16.5 \\
Propylene $\left(\mathrm{C}_{3} \mathrm{H}_{6}\right)$ & - & - & - & 12.2 & - & 8.8 & - & 7.9 \\
1,3-Butadiene $\left(\mathrm{C}_{4} \mathrm{H}_{6}\right)$ & - & - & - & 5.9 & - & 4.3 & - & 4.1 \\
1,3-Cyclopentadiene $\left(\mathrm{C}_{5} \mathrm{H}_{6}\right)$ & - & - & - & 3.5 & - & 2.7 & - & 2.7 \\
Benzene $\left(\mathrm{C}_{6} \mathrm{H}_{6}\right)$ & 0.2 & 23.7 & - & 17.9 & - & 16.6 & - & 14.1 \\
Toluene $\left(\mathrm{C}_{7} \mathrm{H}_{8}\right)$ & - & - & - & 4.8 & - & 4.1 & - & 3.2 \\
\hline
\end{tabular}

\subsection{Analysis of Rh-Ni-Al Catalyst Before and After Reaction in the Presence of Aromatic Hydrocarbon}

The morphology and amounts of carbon on the catalytic surface were observed via SEM-EDX analysis. High-magnification (10,000x) SEM images are shown in Figure 7. Wire-shaped carbon occurred in N50A, but classification of the carbon morphology occurring in R5A-I, R1N50A, and R2N50A was difficult. Table 4 lists the amount of carbon formed on each catalytic surface after 5-hour reactions as DHM fuel. As shown, $20.89 \mathrm{wt} . \%, 40.59 \mathrm{wt} . \%, 22.05 \mathrm{wt} . \%$, and $21.21 \mathrm{wt} . \%$ of carbon were formed on R5A-I, N50A, R1N50A, and R2N50A, respectively. The amount of carbon in N50A was about two times higher than that of the other catalysts containing Rh metal. Rh metal promoted the gasification or reforming of adsorbed carbon species on Rh-Ni-Al-based catalysts during steam 
reforming of sulfur-doped n-hexadecane [33]. Therefore, this metal was helpful in resisting deposition of carbon from the $\mathrm{C}_{2} \mathrm{H}_{4}$ product onto the catalytic surface.
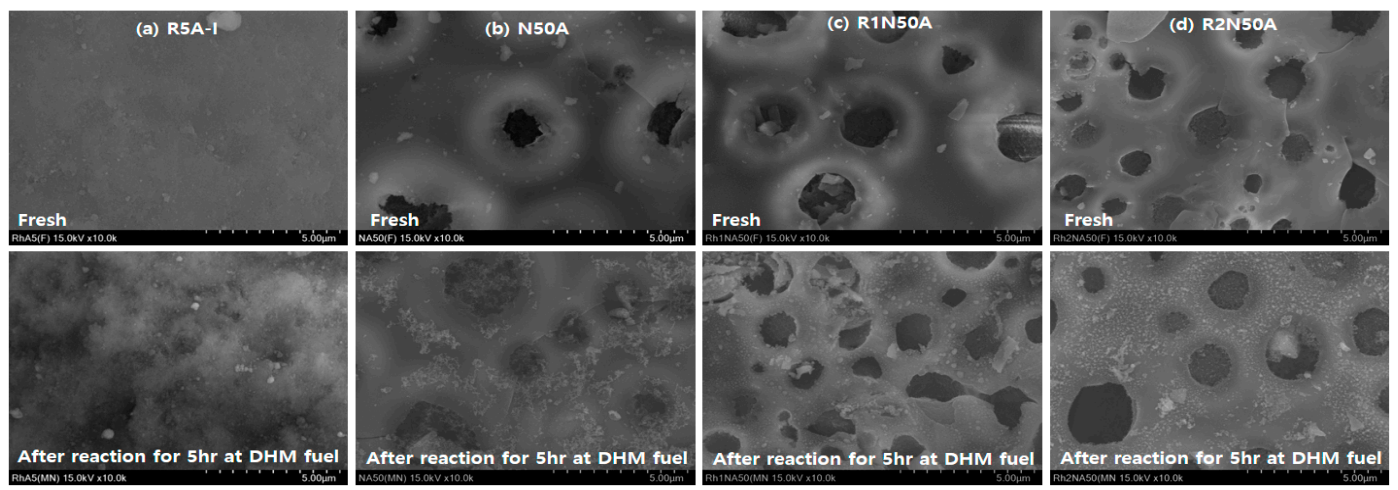

Figure 7. Scanning electron micrographs of (a) R5A-I, (b) N50A, (c) R1N50A, and (d) R2N50A.

Table 4. Amount of carbon on the catalytic surface of R5A-I, N50A, R1N50A, and R2N50A after 5-hour reactions of DHM fuel.

\begin{tabular}{lcccc}
\hline & R5A-I & N50A & R1N50A & R2N50A \\
\hline Carbon (wt.\%) & 20.89 & 40.59 & 22.05 & 21.21 \\
\hline
\end{tabular}

\section{Materials and Methods}

\subsection{Catalyst Preparation}

In our previous studies, various Ni-Al-based catalysts with Fe and Rh promoters were prepared by means of a polymer modified incipient method, to demonstrate the potential of this catalyst preparation method for hydrocarbon fuel reforming [41,42]. The following nomenclature was used for the catalysts: The letters ' $N$ ', ' $R$ ', ' $F$ ', and ' $A$ ' represent $N i, R h, F e$, and $A l$ metal, respectively. In addition, the figures revealed the content (wt.\%) of metal oxide. During the catalyst preparation procedure, known amounts of $\mathrm{Ni}\left(\mathrm{NO}_{3}\right)_{2} \cdot 6 \mathrm{H}_{2} \mathrm{O}$ and $\mathrm{Al}\left(\mathrm{NO}_{3}\right)_{3} \cdot 9 \mathrm{H}_{2} \mathrm{O}$ were dissolved in ethylene glycol $(15 \mathrm{~mL})$ and methyl alcohol (15 mL). Fe $\left(\mathrm{NO}_{3}\right)_{3} \cdot 9 \mathrm{H}_{2} \mathrm{O}$ and $\mathrm{Rh}\left(\mathrm{NO}_{3}\right)_{3} \cdot \times \mathrm{H}_{2} \mathrm{O}$ were added as the precursors for Fe and $\mathrm{Rh}$ metal. The solid products were obtained by heating the solutions with PMMA colloidal crystals (1.5 g) on a hot plate at $100{ }^{\circ} \mathrm{C}$ and drying at $300{ }^{\circ} \mathrm{C}$ for 4 hours. Afterward, the products were calcined at $800^{\circ} \mathrm{C}$ for 4 hours. An Rh-Al-based catalyst (R5A-I) was prepared using a conventional impregnation method, and the catalytic performance of this catalyst was compared with that of the other catalysts. $\mathrm{Rh}\left(\mathrm{NO}_{3}\right)_{3} \cdot \mathrm{HH}_{2} \mathrm{O}$ and $\gamma-\mathrm{Al}_{2} \mathrm{O}_{3}$ were dissolved in water. The resulting solution was stirred at room temperature and the suspension was then evaporated via vacuum evaporation. Afterward, the powder was dried at $300{ }^{\circ} \mathrm{C}$ for 4 hours and then calcined at $800^{\circ} \mathrm{C}$ for 4 hours as per the above conditions.

\subsection{Catalytic Reforming Tests}

The catalysts (mass: $0.5 \mathrm{~g}$, size: 150 to $250 \mu \mathrm{m}$ ) were supported by quartz wool on either side and packed in the middle of a fixed-bed quartz reactor. The quartz reactor was generally used to minimize coke formation on the inner walls. Thermocouple was placed at the center of the catalytic bed and controlled the temperature of the electric furnace. In addition, the temperature was monitored in the inlet and outlet of the reactor. The temperature gradient between the inlet and outlet of the reactor and the catalytic bed was negligible. The mass flow controllers were used to adjust the flow rate of gases such as $\mathrm{H}_{2}, \mathrm{~N}_{2}$, and $\mathrm{O}_{2}$. Enough gas was introduced and the line was heated to prevent condensation. The diesel surrogate fuel was prepared from dodecane $\left(\mathrm{C}_{12} \mathrm{H}_{26}\right)$, hexadecane $\left(\mathrm{C}_{16} \mathrm{H}_{34}\right)$, and 1-methylnaphthalene $\left(\mathrm{C}_{11} \mathrm{H}_{10}\right)$. This fuel varied depending on whether aromatic hydrocarbons (e.g., $\left.\mathrm{C}_{11} \mathrm{H}_{10}\right)$ were contained in diesel surrogate fuels such as $\mathrm{DH}\left(\mathrm{C}_{12} \mathrm{H}_{26}\right.$ and $\mathrm{C}_{16} \mathrm{H}_{34}$ mixture) 
and DHM (DH fuel and $\mathrm{C}_{11} \mathrm{H}_{10}$ mixture) fuel. The selected diesel surrogate fuel and $\mathrm{H}_{2} \mathrm{O}$ were injected by syringe pumps and completely vaporized with $\mathrm{N}_{2}$ at $400{ }^{\circ} \mathrm{C}$ in the vaporizer. Afterward, the condensable liquids were completely removed before injection into gas chromatograph (GC, Agilent 6890, Santa Clara, CA, USA). Product gases such as $\mathrm{H}_{2}, \mathrm{~N}_{2}, \mathrm{CO}, \mathrm{CH}_{4}$, and $\mathrm{CO}_{2}$ were then analyzed via GC-TCD (thermal conductivity detector). Supplementary Materials Figure S2 shows the schematic diagram of experimental apparatus. In addition, $\mathrm{CO}_{2}$ and hydrocarbons, such as ethane $\left(\mathrm{C}_{2} \mathrm{H}_{6}\right)$, ethylene $\left(\mathrm{C}_{2} \mathrm{H}_{4}\right)$, propylene $\left(\mathrm{C}_{3} \mathrm{H}_{6}\right)$, 1,3-butadiene $\left(\mathrm{C}_{4} \mathrm{H}_{6}\right)$, 1,3-cyclopentadiene $\left(\mathrm{C}_{5} \mathrm{H}_{6}\right)$, benzene $\left(\mathrm{C}_{6} \mathrm{H}_{6}\right)$, and toluene $\left(\mathrm{C}_{7} \mathrm{H}_{8}\right)$, were detected via GC-MS (Agilent (7890B-5977B GC/MSD), Santa Clara, CA, USA). The $\mathrm{H}_{2}$ pre-reduction treatments were conducted for 2 hours at $750{ }^{\circ} \mathrm{C}$ prior to the tests. The catalytic performance of each catalyst was investigated under the following conditions: $\mathrm{S} / \mathrm{C}=1.17, \mathrm{O}_{2} / \mathrm{C}=0.24$, $750{ }^{\circ} \mathrm{C}$, and GHSV $=12,000 \mathrm{~h}^{-1}$ at DH or DHM fuel. The diesel surrogate fuel conversions and the selectivity of product gases were calculated as follows.

$$
\begin{aligned}
& \text { Conversion (\%) }=\left(\frac{\mathrm{F}_{\mathrm{CO} \cdot \mathrm{Out}}+\mathrm{F}_{\mathrm{CO}_{2} \cdot \mathrm{Out}}+\mathrm{F}_{\mathrm{CH}_{4} \cdot \text { Out }}}{\mathrm{F}_{\mathrm{C}_{12} \mathrm{H}_{26} \cdot \operatorname{In}} \times 12+\mathrm{F}_{\mathrm{C}_{16} \mathrm{H}_{34} \cdot \mathrm{In}} \times 16+\mathrm{F}_{\mathrm{C}_{11} \mathrm{H}_{10} \cdot \text { In }} \times 11}\right) \times 100
\end{aligned}
$$

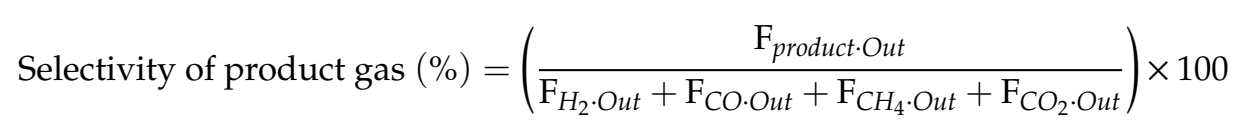

\subsection{Characterization}

The morphology and the amounts of carbon on the catalytic surface were determined via FE-SEM (S-4300, Hitachi, Tokyo, Japan) and EDX (EDX-350, Hitachi, Tokyo, Japan), respectively. The crystal structure of each catalyst was determined via XRD using a $\mathrm{CuK} \alpha$ radiation source (Phillips XPERT instrument, Korea Basic Science Institute, Daegu). Furthermore, the phases comprising the mixed metal oxides were identified via XPS (Quantera SXM, ULVAC-PHI, Chigasaki, Japan).

\section{Conclusions}

To investigate the effect of aromatic hydrocarbon on the autothermal reforming of diesel, 1-methylnaphthalene $\left(\mathrm{C}_{11} \mathrm{H}_{10}\right)$ was selected and blended as an aromatic hydrocarbon. Two types of diesel surrogate fuel, i.e., $\mathrm{DH}\left(\mathrm{C}_{12} \mathrm{H}_{26}\right.$ and $\mathrm{C}_{16} \mathrm{H}_{34}$ mixture) and $\mathrm{DHM}$ (DH fuel and $\mathrm{C}_{11} \mathrm{H}_{10}$ mixture) fuels, were prepared. The R5A-I, Ni-Al-based catalyst, and Fe-Ni-Al-based catalyst maintained catalytic performances for 5 hours using DH fuel, whereas the catalysts except for R5A-I became deactivated at DHM fuel. Unsurprisingly, the Fe promoter of the Ni-Al-based catalysts yielded no improvement in the catalytic performance at DHM fuel. When an Rh metal was added to these catalysts, the resulting catalytic performance was superior to that achieved for the other catalysts. The extent of catalyst deactivation decreased with greater content of this metal as a promoter. Although expensive, the Rh metal acted as a remarkable promoter that improved the resistance property of aromatic carbon for autothermal reforming of diesel fuel. The GC-MS data revealed that, among the produced hydrocarbons, $\mathrm{C}_{2} \mathrm{H}_{4}$ played a major role in deactivating the catalysts, since this hydrocarbon resulted in carbon deposition that covered the $\mathrm{Ni}$ metal active sites. In conclusion, the catalytic performance of Ni-Al-based catalysts, which are susceptible to accelerated carbon deposition from the $\mathrm{C}_{2} \mathrm{H}_{4}$ product, can be improved through the addition of small amounts of Rh metal.

Supplementary Materials: The following are available online at http://www.mdpi.com/2073-4344/9/7/573/s1. Figure S1: Conversions of the blank test, N10A, N30A, and N50A at DHM fuel, Figure S2 The schematic diagram of experimental apparatus.

Author Contributions: Conceptualization, D.G.J., D.S.H., and S.Y.J. Data curation, T.Y.K. and H.J.C. Investigation, D.G.J. and D.S.H. Supervision, S.Y.J., S.C.L., and J.C.K. Writing - original draft, D.C.J. Writing - review \& editing, S.B.J.

Funding: This research was funded by The Korea Institute of Energy Technology Evaluation and Planning (KETEP) and the Ministry of Trade, Industry \& Energy (MOTIE) of the Republic of Korea (No.20173010050110" and "The Kyungpook National University Development Project Research Fund. 
Acknowledgments: The Korea Institute of Energy Technology Evaluation and Planning (KETEP) and the Ministry of Trade, Industry \& Energy (MOTIE) of the Republic of Korea supported this work (No.20173010050110). The Kyungpook National University Development Project Research Fund, 2018, also supported this research.

Conflicts of Interest: The authors declare no conflict of interest.

\section{References}

1. Balat, M. Potential importance of hydrogen as a future solution to environmental and transportation problems. Int. J. Hydrogen Energy 2008, 33, 4013-4029. [CrossRef]

2. Afgan, N.; Veziroglu, A. Sustainable resilience of hydrogen energy system. Int. J. Hydrogen Energy 2012, 37, 5461-5467. [CrossRef]

3. Zheng, J.; Liu, X.; Xu, P.; Liu, P.; Zhao, Y.; Yang, J. Development of high pressure gaseous hydrogen storage technologies. Int. J. Hydrogen Energy 2012, 37, 1048-1057. [CrossRef]

4. Megede, D.Z. Fuel processors for fuel cell vehicles. J. Power Sources 2002, 106, 35-41. [CrossRef]

5. Aicher, T.; Lenz, B.; Gschnell, F.; Groos, U.; Federici, F.; Caprile, L.; Parodi, L. Fuel processors for fuel cell APU applications. J. Power Sources 2006, 154, 503-508. [CrossRef]

6. Lindström, B.; Karlsson, J.A.J.; Ekdunge, P.; De Verdier, L.; Häggendal, B.; Dawody, J.; Nilsson, M.; Pettersson, L.J. Diesel fuel reformer for automotive fuel cell applications. Int. J. Hydrogen Energy 2009, 34, 3367-3381. [CrossRef]

7. Yoon, S.H.; Bae, J.M.; Lee, S.H.; Pham, T.V.; Katikaneni, S.P. A diesel fuel processor for stable operation of solid oxide fuel cells system: II. Integrated diesel fuel processor for the operation of solid oxide fuel cells. Int. J. Hydrogen Energy 2012, 37, 9228-9236. [CrossRef]

8. Yoon, S.H.; Bae, J.M. A diesel fuel processor for stable operation of solid oxide fuel cells system: I. Introduction to post-reforming for the diesel fuel processor. Catal. Today 2010, 156, 49-57. [CrossRef]

9. Gerardo, V.H.; Johanan, Á.J.; Tobias, M.; Michael, D.; Keno, L.; Stephan, K. Exergy analysis of the diesel pre-reforming SOFC-system with anode off-gas recycling in the SchIBZ project. Part II: System exergetic evaluation. Int. J. Hydrogen Energy 2019, 44, 10916-10924.

10. Bali, A.; Blanchard, J.; Chamoumi, M.; Abatzoglou, N. Bio-Oil Steam Reforming over a Mining Residue Functionalized with Ni as Catalyst Ni-UGSO. Catalysts 2018, 8, 1. [CrossRef]

11. Kim, D.H.; Kang, J.S.; Lee, Y.J.; Park, N.K.; Kim, Y.C.; Hong, S.I.; Moon, D.J. Steam reforming of n-hexadecane over noble metal-modified Ni-based catalysts. Catal. Today 2008, 136, 228-234. [CrossRef]

12. Fauteux-Lefebvre, C.; Abatzoglou, N.; Blanchard, J.; Gitzhofer, F. Steam reforming of liquid hydrocarbons over a nickel-alumina spinel catalyst. J. Power Sources 2010, 195, 3275-3283. [CrossRef]

13. Peymani, M.; Alavi, S.M.; Arandiyan, H.; Rezaei, M. Rational Design of High Surface Area Mesoporous $\mathrm{Ni} / \mathrm{CeO}_{2}$ for Partial Oxidation of Propane. Catalysts 2018, 8, 388. [CrossRef]

14. Navarro, R.M.; Alvarez-Galvan, M.C.; Rosa, F.; Fierro, J.L.G. Hydrogen production by oxidative reforming of hexadecane over $\mathrm{Ni}$ and Pt catalysts supported on Ce/La-doped $\mathrm{Al}_{2} \mathrm{O}_{3}$. Appl. Catal. A Gen 2006, 297, 60-72. [CrossRef]

15. Wang, Z.; Huang, H.; Liu, H.; Zhou, X. Self-sustained electrochemical promotion catalysts for partial oxidation reforming of heavy hydrocarbons. Int. J. Hydrogen Energy 2012, 37, 17928-17935. [CrossRef]

16. Kang, I.Y.; Bae, J.M. Autothermal reforming study of diesel for fuel cell application. J. Power Sources 2006, 159, 1283-1290. [CrossRef]

17. Deivanayagam, H.; Ruinan, Y.; Yingcong, Z.; Brian, G.; Sotirios, M.; Robyn, E.S.; Michael, A.L.; Marco, J.C.; Rajinder, G.; Andrew, D.; et al. Catalytic partial oxidation reformation of diesel, gasoline, and natural gas for use in low temperature combustion engines. Fuel 2019, 246, 295-307.

18. Savvas, L.D.; Nikolaos, D.C.; Kyriakos, N.P.; Maria, A.G. Green Diesel: Biomass Feedstocks, Production Technologies, Catalytic Research, Fuel Properties and Performance in Compression Ignition Internal Combustion Engines. Energies 2019, 12, 809.

19. Parmar, R.D.; Kundu, A.; Karan, K. Thermodynamic analysis of diesel reforming process: Mapping of carbon formation boundary and representative independent reactions. J. Power Sources 2009, 194, 1007-1020. [CrossRef] 
20. Mueller, C.J.; Cannella, W.J.; Bays, J.T.; Bruno, T.J.; DeFabio, K.; Dettman, H.D.; Gieleciak, R.M.; Huber, M.L.; Kweon, C.B.; McConnell, S.S.; et al. Diesel Surrogate Fuels for Engine Testing and Chemical-Kinetic Modeling: Compositions and Properties. Energy Fuels 2016, 30, 1445-1461.

21. Gonzalez, A.V.; Pettersson, L.J. Full-scale autothermal reforming for transport applications: The effect of diesel fuel quality. Catal. Today 2013, 210, 9-25. [CrossRef]

22. Huseyin, A. Effect of impregnation sequence of $\mathrm{Mg}$ on performance of mesoporous alumina supported $\mathrm{Ni}$ catalyst in dry reforming of methane. Int. J. Hydrogen Energy 2018, 43, 6561-6574.

23. Dori, Y.K.; Kristian, S.; Yiying, J.; Wakshum, M.T.; Zhixin, Y. Biogas dry reforming for syngas production on La promoted hydrotalcite-derived Ni catalysts. Int. J. Hydrogen Energy 2018, 43, 19438-19450.

24. Norazimah, H.; Sumaiya, Z.A.; Osarieme, U.O.; Yun, H.T.; Mohammad, T.A. Hydrogen production from glycerol dry reforming over $\mathrm{Ag}$-promoted $\mathrm{Ni} / \mathrm{Al}_{2} \mathrm{O}_{3}$. Int. J. Hydrogen Energy 2019, 44, $213-225$.

25. Zhanfeng, H.; Yi, J.; Jianli, W.; Yaoqiang, C. Bi-functional composite oxides $\mathrm{M}(\mathrm{Na}, \mathrm{K})-\mathrm{Ni} / \mathrm{La}-\mathrm{Al}_{2} \mathrm{O}_{3}$ catalysts for steam reforming of n-decane. Fuel 2018, 212, 193-201.

26. Ferrandon, M.; Krause, T. Role of the oxide support on the performance of Rh catalysts for the autothermal reforming of gasoline and gasoline surrogates to hydrogen. Appl. Catal. A Gen 2006, 311, 135-145. [CrossRef]

27. Tribalis, A.; Panagiotou, G.D.; Bourikas, K.; Sygellou, L.; Kennou, S.; Ladas, S.; Lycourghiotis, A.; Kordulis, C. Ni Catalysts Supported on Modified Alumina for Diesel Steam Reforming. Catalysts 2016, 6, 11. [CrossRef]

28. Hanyu, C.; Xi, W.; Zhixiang, P.; Hongming, X. Numerical Simulation and Experimental Investigation of Diesel Fuel Reforming over a $\mathrm{Pt} / \mathrm{CeO}_{2}-\mathrm{Al}_{2} \mathrm{O}_{3}$ Catalyst. Energies 2019, 12, 1056.

29. Cai, W.J.; Qian, L.P.; Yue, B.; He, H.Y. Rh doping effect on coking resistance of Ni/SBA-15 catalysts in dry reforming of methane. Chin. Chem. Lett. 2014, 25, 1411-1415. [CrossRef]

30. Hou, Z.; Yashima, T. Small amounts of Rh-promoted Ni catalysts for methane reforming with $\mathrm{CO}_{2}$. Chin. Chem. Lett. 2003, 89, 3-4.

31. Strohm, J.J.; Zheng, J.; Song, C. Low-temperature steam reforming of jet fuel in the absence and presence of sulfur over Rh and Rh-Ni catalysts for fuel cells. J. Catal. 2006, 238, 309-320. [CrossRef]

32. Kaila, R.K.; Gutierrez, A.; Krause, A.O.I. Autothermal reforming of simulated and commercial diesel: The performance of zirconia-supported RhPt catalyst in the presence of sulfur. Appl. Catal. B Environ. 2008, 84, 324-331. [CrossRef]

33. Lakhapatri, S.L.; Abraham, M.A. Deactivation due to sulfur poisoning and carbon deposition on $\mathrm{Rh}-\mathrm{Ni} / \mathrm{Al}_{2} \mathrm{O}_{3}$ catalyst during steam reforming of sulfur-doped n-hexadecane. Appl. Catal. A Gen. 2009, 364, 113-121. [CrossRef]

34. Karatzas, X.; Jansson, K.; Gonzalez, A.; Dawody, J.; Pettersson, L.J. Autothermal reforming of low-sulfur diesel over bimetallic $\mathrm{RhPt}$ supported on $\mathrm{Al}_{2} \mathrm{O}_{3}, \mathrm{CeO}_{2}-\mathrm{ZrO}_{2}, \mathrm{SiO}_{2}$ and $\mathrm{TiO}_{2}$. Appl. Catal. B Environ. 2011, 106, 476-487. [CrossRef]

35. Zheng, Q.; Janke, C.; Farrauto, R. Steam reforming of sulfur-containing dodecane on a Rh-Pt catalyst: Influence of process parameters on catalyst stability and coke structure. Appl. Catal. B Environ. 2014, 160-161, 525-533. [CrossRef]

36. Vita, A.; Italiano, C.; Pino, L.; Lagana, M.; Recupero, V. Hydrogen-rich gas production by steam reforming of n-dodecane. Part II: Stability, regenerability and sulfur poisoning of low loading Rh-based catalyst. Appl. Catal. B Environ. 2017, 218, 317-326. [CrossRef]

37. Karatzas, X.; Dawody, J.; Grant, A.; Svensson, E.E.; Pettersson, L.J. Zone-coated Rh-based monolithic catalyst for autothermal reforming of diesel. Appl. Catal. B Environ. 2011, 101, 226-238. [CrossRef]

38. Karatzas, X.; Jansson, K.; Dawody, J.; Lanza, R.; Pettersson, L.J. Microemulsion and incipient wetness prepared Rh-based catalyst for diesel reforming. Catal. Today 2011, 175, 515-523. [CrossRef]

39. Shoynkhorova, T.B.; Simonov, P.A.; Potemkin, D.I.; Snytnikov, P.V.; Belyaev, V.D.; Ishchenko, A.V.; Svintsitskiy, D.A.; Sobyanin, V.A. Highly dispersed Rh-, Pt-, $\mathrm{Ru} / \mathrm{Ce}_{0.75} \mathrm{Zr}_{0.25} \mathrm{O}_{2}-\delta$ catalysts prepared by sorption-hydrolytic deposition for diesel fuel reforming to syngas. Fuel 2018, 237, 237-244.

40. Rogozhnikov, V.N.; Kuzin, N.A.; Snytnikov, P.V.; Potemkin, D.I.; Shoynkhorova, T.B.; Simonov, P.A.; Shilov, V.A.; Ruban, N.V.; Kulikov, A.V.; Sobyanin, V.A. Design, scale-up, and operation of a $\mathrm{Rh} / \mathrm{Ce}_{0.75} \mathrm{Zr}_{0.25} \mathrm{O}_{2-\delta}-\eta-\mathrm{Al}_{2} \mathrm{O}_{3} / \mathrm{FeCrAl}$ alloy wire mesh honeycomb catalytic module in diesel autothermal reforming. Chem. Eng. J. 2019, 374, 511-519. [CrossRef]

41. Lee, W.S.; Ju, D.G.; Jung, S.Y.; Lee, S.C.; Ha, D.S.; Hwang, B.W.; Kim, J.C. N-Dodecane Autothermal Reforming Properties of Ni-Al Based Catalysts Prepared by Various Methods. Top. Catal 2017, 60, 727-734. [CrossRef] 
42. Jung, S.Y.; Ju, D.G.; Lim, E.J.; Lee, S.C.; Hwang, B.W.; Kim, J.C. Study of sulfur-resistant Ni-Al-based catalysts for autothermal reforming of dodecane. Int. J. Hydrogen Energy 2015, 40, 13412-13422. [CrossRef]

43. Yoon, S.H.; Kang, I.Y.; Bae, J.M. Effects of ethylene on carbon formation in diesel autothermal reforming. Int. J. Hydrogen Energy 2008, 33, 4780-4788. [CrossRef]

44. Trabold, T.A.; Lylak, J.S.; Walluk, M.R.; Lin, J.F.; Troiani, D.R. Measurement and analysis of carbon formation during diesel reforming for solid oxide fuel cells. Int. J. Hydrogen Energy 2012, 37, 5190-5201. [CrossRef]

45. Jo, S.B.; Ju, D.G.; Jung, S.Y.; Ha, D.S.; Chae, H.J.; Lee, S.C.; Kim, J.C. Performance of an Auto-Reduced Nickel Catalyst for Auto-Thermal Reforming of Dodecane. Catalysts 2018, 8, 371. [CrossRef]

46. Bang, Y.; Han, S.J.; Seo, J.G.; Youn, M.H.; Song, J.H.; Song, I.K. Hydrogen production by steam reforming of liquefied natural gas (LNG) over ordered mesoporous nickel-alumina catalyst. Int. J. Hydrogen Energy 2012, 37, 17967-17977. [CrossRef]

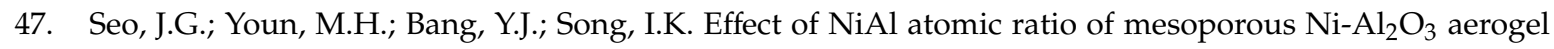
catalysts on their catalytic activity for hydrogen production by steam reforming of liquefied natural gas (LNG). Int. J. Hydrogen Energy 2010, 35, 12174-12181. [CrossRef]

48. Wang, Y.; Song, Z.; Ma, D.; Luo, H.; Liang, D.; Bao, X. Characterization of Rh-based catalysts with EPR, TPR, IR and XPS. J. Mol. Catal. A: Chem 1999, 149, 51-61. [CrossRef]

49. Osaki, T.; Mori, T. Characterization of nickel-alumina aerogels with high thermal stability. J. Non-Cryst. Solids 2009, 355, 1590-1596. [CrossRef]

50. Obu-Cann, K.; Tokutaka, H.; Fujimura, K.; Yoshihara, K.; Metal Materials Group of SASJ. Chemical Analysis of XPS (X-ray Photoelectron Spectroscopy) Data using Self-Organising Maps. J. Surf. Anal. 1999, 6, 85-86.

(C) 2019 by the authors. Licensee MDPI, Basel, Switzerland. This article is an open access article distributed under the terms and conditions of the Creative Commons Attribution (CC BY) license (http://creativecommons.org/licenses/by/4.0/). 